\title{
A RARE CASE OF HYPERCALCEMIC ENCEPHALOPATHY IN A CASE OF CARCINOMA ESOPHAGUS WITH COEXSISTING LEIOMYOSARCOMA OF STOMACH
}

Nandiniswamy ${ }^{1}$, Ravikumar ${ }^{2}$, Sanjeev ${ }^{3}$, Anil ${ }^{4}$, Sai Shruthi ${ }^{5}$

\section{HOW TO CITE THIS ARTICLE:}

Nandiniswamy, Ravikumar, Sanjeev, Anil, Sai Shruthi. "A Rare Case of Hypercalcemic Encephalopathy in a Case of Carcinoma Esophagus with Coexisting Leiomyosarcoma of Stomach". Journal of Evolution of Medical and Dental Sciences 2014; Vol. 3, Issue 14, April 07; Page: 3682-3684, D0I: 10.14260/jemds/2014/2343

\begin{abstract}
ABSRACT: A 50-year-old man presented to hospital with non-specific symptoms such as anorexia, nausea, dehydration, weight loss, fatigue, generalized weakness, and lethargy. His Serum level of calcium was markedly increased $16.2 \mathrm{mg} / \mathrm{dL}$ (8.6-10.2 $\mathrm{mg} / \mathrm{dL}$ ) and parathyroid hormone (PTH) was 9.4 IU (2-11 IU), CT Abdomen was S/O leiomyosarcoma of stomach, upper GI scopy revealed growth in mid esophagus, biopsy was done and histology showed squamous cell carcinoma. Hypercalcemia was corrected and patient improved.
\end{abstract}

KEYWORDS: Hypercalcemia, esophagus, leiomyosarcoma, encephalopathy.

INTRODUCTION: Hypercalcemia can occur in patients with various disorders and hypercalcemia in malignancy as part of a paraneoplastic syndrome is one of the leading cause. Traditionally, humoral hypercalcemia of malignancy is referred to the over production of parathyroid hormone-related peptide (PTHrP). ${ }^{1}$ This report describes an unusual case of paraneoplastic hypercalcemic encephalopathy occurring in squamous cell carcinoma of esophagus with coexisting leiomyosarcoma of stomach.

CASE REPORT: A 62-year-old man was admitted to ICU with $\mathrm{H} / 0$ altered sensorium and dyspnea at rest, with h/0 significant weight loss, there was no h/o vomiting, dysphagia, trauma or weakness. Patient had past h/o COPD .0/E, PR-138BPM, BP-140/80mmhg, respiratory examination was normal expect for occasional rhonchi, CNS examination revealed no focal neurological deficits, Abdomen examination was essentially normal.

Following investigation was done, CXR-normal, ECG -short QT interval, Hemoglobin was -7.3 $\mathrm{g} / \mathrm{dl}$, ESR $40 \mathrm{~mm}$, serum creatinine $2.3 \mathrm{mg} / \mathrm{dl}$, blood urea $126 \mathrm{mg}$, liver function test was normal. MRI brain S/O-acute infarct in corona radiata and was started on antiplatelets. His serum calcium was 16 $\mathrm{mg} / \mathrm{dl}$, phosphate $-2.8 \mathrm{mg} / \mathrm{dl}$, PTH 11- IU, CT- ABDOMEN S/O large gastric mass compressing pancreas and portal vein probably leiomyosarcoma of stomach (FIG-1), upper GI endoscopy showed growth in the mid esophagus (FIG-2), thickening of gastric mucosa, histopathology examination revealed squamous cell carcinoma of esophagus and gastric mucosal biopsy was negative for malignancy consistent with leiomyosarcoma.

Patient was treated with adequate hydration, diuretics, zolendronic acid, patient sensorium improved, repeat serum calcium was $7.8 \mathrm{mg}$, and serum creatinine was $1.1 \mathrm{mg} / \mathrm{dl}$. Patient was discharged in stable condition.

DISCUSSION: Esophageal cancer is the eighth most common cancer worldwide, and is the 6th most common cause of cancer death in the world. Malignancy-associated hypercalcemia occurs in up to 
$10 \%$ of all patients with advanced cancer and generally conveys a poor prognosis. Indeed, the 30-day mortality rate for cancer patients with hypercalcemia is approximately $50 \% 2$. There are many principal mechanisms of hypercalcemia in cancer patients. Secretion of parathyroid hormone (PTH)related protein (PTHrP) by tumor cells known as humoral hypercalcemia of malignancy accounts for $80 \%$ of cases and occurs most commonly with squamous cell tumors ${ }^{3}$.

Hypercalcemia is the most frequent paraneoplastic syndrome observed in patients with cancer commonly seen in carcinoma lung and kidney. Hypercalcemia in case of esophageal squamous cell carcinoma is infrequently reported, and incidence is $1.3 \%$ hypercalcemia is thought to be due to $\mathrm{PTHrP}^{4}$, . Severe hypercalcemia is associated with encephalopathy, hypercalcemic nephropathy and cardiac arrhythmia.

There is no evidence demonstrating paraneoplastic hypercalcemia in case of leiomyosarcomas but rare existence cannot be ruled out. The coexistence of leiomyosarcoma and carcinoma esophagus with paraneoplastic hypercalcemia has been reported in very few cases.

\section{REFERENCES:}

1. Williams et al. Hypercalcemia in patients with esophageal carcinoma: The pathophysiologic role of parathyroid hormone-related protein. Cancer 1991; 68(12):2625-29.

2. Stephens RL, Hansen HH, Muggia FM. Hypercalcemia in epidermoid tumors of the head and neck and esophagus. Cancer 1973; 31: 1487-1491.

3. Mann NS, Sachdev AJ. Carcinoma of the esophagus and hypercalcemia. Am J Gastroenterol 1997; 67: 135-140.

4. Tsuchihashi T, Yamaguchi K, Miyake Y. Parathyroid hormone-related protein in tumor tissues obtained from patients with humoral hypercalcemia of malignancy. J Natl Cancer Inst 1990; 82: 40-44.

5. Futugwa M, Kimusira J. A case of esophageal squamous cell carcinoma associated with hypercalcemia. Fukushima journal of medical science 07/2007; 53(1):51-60.

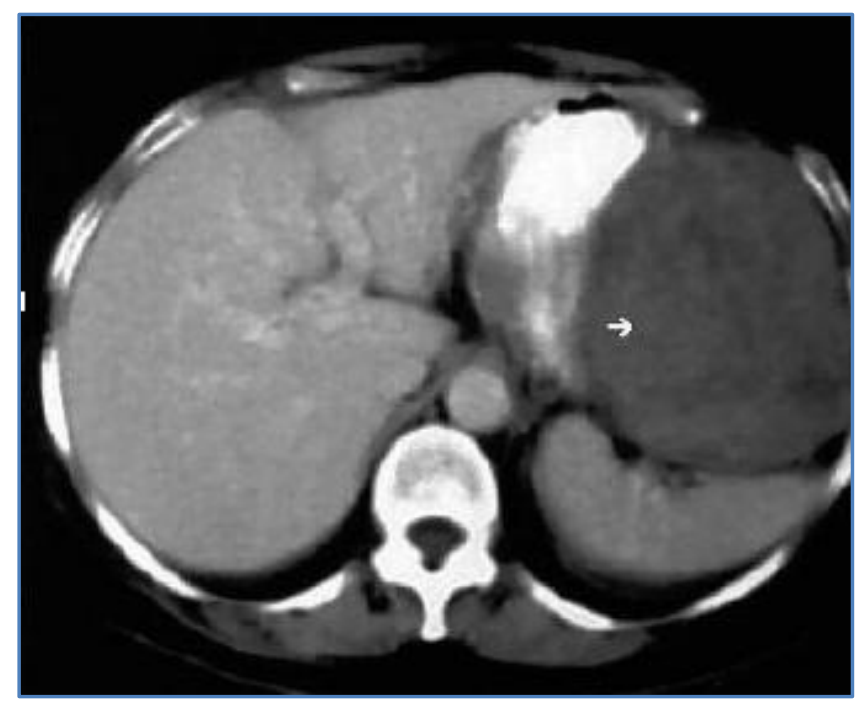

Fig. 1: C T- IMAGE LEIOMYOSARCOMA 


\section{CASE REPORT}

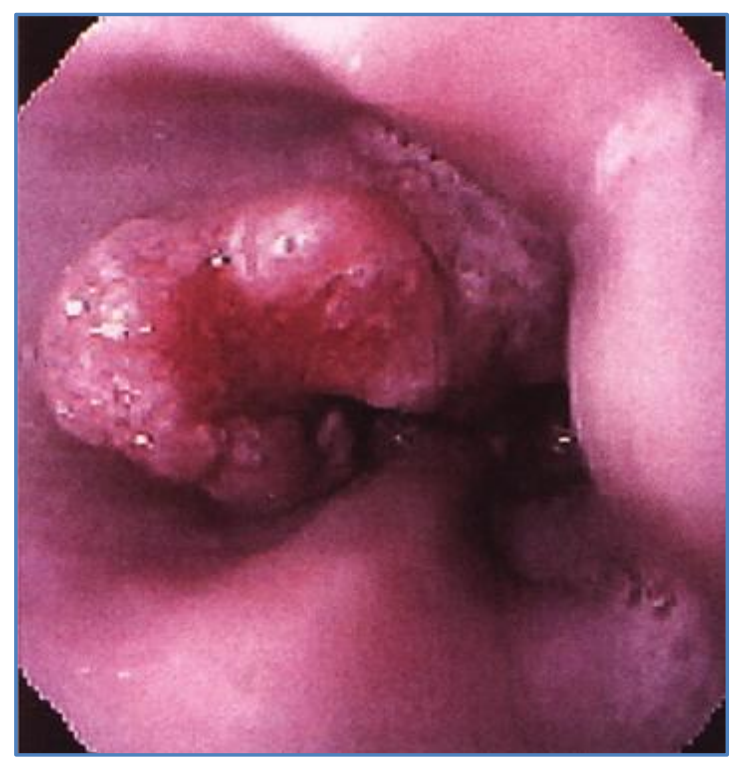

Fig. 2: ESOPHAGEAL CARCINOMA

\section{AUTHORS:}

1. Nandiniswamy

2. Ravikumar

3. Sanjeev

4. Anil

5. Sai Shruthi

\section{PARTICULARS OF CONTRIBUTORS:}

1. Associate Professor, Department of Internal Medicine, ESIC MC \& PGIMSR.

2. Post Graduate, Department of Internal Medicine, ESIC MC \& PGIMSR.

3. Post Graduate, Department of Internal Medicine, ESIC MC \& PGIMSR.

4. Post Graduate, Department of Internal Medicine, ESIC MC \& PGIMSR.
5. Post Graduate, Department of Internal Medicine, ESIC MC \& PGIMSR.

\section{NAME ADDRESS EMAIL ID OF THE CORRESPONDING AUTHOR:}

Dr. Ravi Kumar,

PG Hostel, Room No. F8,

ESIC MC, PGIMSR,

Rajajinagar, Bangalore - 560010 .

E-mail: ryakha@gmail.com

Date of Submission: 07/03/2014.

Date of Peer Review: 08/03/2014.

Date of Acceptance: 21/03/2014.

Date of Publishing: 04/04/2014. 